\title{
Eutrophication in coastal marine ecosystems: towards better understanding and management strategies
}

\author{
J. H. Andersen · D. J. Conley
}

Published online: 27 April 2009

(C) The Author(s) 2009. This article is published with open access at Springerlink.com

The Second International Symposium on Research and Management of Eutrophication in Coastal Ecosystems took place 20-23 June 2006 in Nyborg, Denmark. The Symposium was attended by more than 200 persons with a specific interest in eutrophication processes as well as a common interest in science-based management and implementation of nutrient reduction strategies. More than 120 oral presentations were made, mostly focussing on both science and management of nutrient enrichment and eutrophication. The papers in this Special Issue of Hydrobiologia are all based on presentations made at the Symposium.

Electronic supplementary material The online version of this article (doi:10.1007/s10750-009-9758-0) contains supplementary material, which is available to authorized users.

Guest editors: J. H. Andersen \& D. J. Conley

Eutrophication in Coastal Ecosystems: Selected papers from the Second International Symposium on Research and Management of Eutrophication in Coastal Ecosystems, 20-23 June 2006, Nyborg, Denmark

J. H. Andersen $(\bowtie)$

DHI, Agern Allé 5, 2970 Hørsholm, Denmark

e-mail: jha@dhi.dk

D. J. Conley

Department of Geology, GeoBiosphere Science Centre,

Lund University, Sölvegatan 12, 22362 Lund, Sweden

\section{About the symposium}

The symposium focused on the following four topics: (1) new and existing knowledge regarding coastal eutrophication, (2) specific eutrophication issues such as: (a) definition(s) and causes, (b) nutrient cycling and nutrient limitation, (c) reference conditions and (d) linkages to other pressures (climate change and top/down control), (3) summaries of existing knowledge in relation to monitoring and modelling coastal eutrophication and (4) adaptive environmental management strategies in relation to coastal eutrophication.

The symposium was jointly organised by the Danish Environmental Protection Agency (EPA), the Swedish EPA, Fyn County and DHI Water \& Environment and received financial support from the organising institutions. In addition, the Symposium has been kindly sponsored by: (1) Baltic Sea 2020, (2) Danish Agriculture, (3) the International Agency for ${ }^{14} \mathrm{C}$ Determination, (4) MARE-the Swedish Marine Eutrophication Research Programme and (5) the University of Southern Denmark. Further, the symposium received support from the European Commission's Joint Research Centre, Hotel Nyborg Strand and Scandinavian Airlines Systems (SAS).

The planning of the symposium was coordinated by an Organising Committee with the overall responsibility and a Scientific Committee which compiled a broad programme focussing on both science and management. A list of members of the 
committees is available as supplementary online material.

\section{Eutrophication research and management-the Danish connection}

The symposium was a follow up to the highly successful 1993 Symposium Nutrient Dynamics in Coastal and Estuarine Environments, organised by the Danish EPA in collaboration with the European Commission, Directorate-General for Science, Research and Development. The Symposium Proceedings were published in the journal Ophelia with several seminal papers, for example, Duarte (1995), Nixon (1995) and Richardson \& Heilmann (1995).

There was great regional and international interest for a follow-up symposium with a focus on both science and management. This interest in science and management has been stimulated by legislative settings, particularly the EU Water Framework Directive, in which coastal eutrophication problems are important issues in adaptive management plans (Anon., 2000).

During recent decades, Denmark and Sweden have been at the forefront of research on and management of eutrophication in coastal marine ecosystems (Jørgensen \& Richardson, 1996; Christensen et al., 1998; Carstensen et al., 2006; Table 1), partly because the straits between Denmark and Sweden connecting the Baltic Sea to the North Sea are vulnerable to nutrient enrichment. Denmark and neighbouring countries have made substantial efforts to improve the marine environment through nutrient reductions both at the national level and through decades of regional cooperation regarding the Baltic Sea under the Helsinki Convention (www.helcom.fi) and the North Sea through the OSPAR Convention (www.ospar.org).

Both Denmark (Fig. 1) and Sweden have made large reductions in the discharge of nutrients. Billions of Euros have been spent, and they have not been spent in vain. The point source inputs of nutrients to the marine environment are significantly lower than they were 20 years ago. However, these reductions have not been sufficient to reduce the harmful effects of eutrophication and the targets for improved ecological status have not been reached.
Three Danish Action Plans for the Aquatic Environment over the past two decades (Conley et al., 2002) have resulted in significant reductions in the loss of nutrients to the environment (Conley et al., 2002; Carstensen et al., 2006). Point source inputs of phosphorus have decreased by more than $80 \%$. Losses of nitrogen are expected to be reduced by $\sim 50 \%$ when changes in agricultural practises that have already been implemented result in reduced loads to the marine environment. Figure 1 shows the temporal trends in total nitrogen loading to the Kattegat and Danish Straits over a 100-year period, with a peak in total nitrogen loading in the 1980s.

Since the late 1970s, loads originating from both point sources and diffuse sources have been declining. However, more than three decades since the first measures were implemented and more than a decade after the First International Danish Symposium on eutrophication, the problems associated with eutrophication are still far from being resolved. There has been a major development in scientific knowledge and in the conceptual understanding of nutrient enrichment and eutrophication in coastal waters. New questions and challenges have emerged, especially in relation to modelling and management of coastal eutrophication. In parallel, new legal and management settings have emerged or will emerge in the near future, for example, the EU Water Framework Directive and the process in relation to the implementation of the European Marine Strategy. Therefore, it was proposed and agreed in 2004 that a follow-up symposium focussing on both science and management of coastal eutrophication should be organised for June 2006.

\section{About this Special Issue}

The 21 papers in this Special Issue are a mixture of Research Papers, Opinion Papers and Short Notes, which reflect the broad range of presentations at the June 2006 symposium. Each manuscript was reviewed by at least two independent reviewers and by one of the guest editors. Copy editing was conducted by Janet F. Pawlak and Carolyn Symon. The Special Issue has received direct financial support from the Nordic Council of Ministers via the working group on the Sea and Atmosphere 
Table 1 Danish nutrient reduction targets sensu the Action Plans for the Aquatic Environment I, II and III. Baseline is 1987; reductions and targets were agreed by the Danish Parliament in 1987 and subsequently adjusted in 1990, 1999 and 2004

\begin{tabular}{|c|c|c|c|c|c|c|c|c|c|c|c|c|}
\hline \multirow[t]{2}{*}{ Sector } & \multicolumn{6}{|c|}{ Total nitrogen loads (tonnes) } & \multicolumn{6}{|c|}{ Total phosphorus loads (tonnes) } \\
\hline & 1987 & $\div$ & Reduction & $\%$ & $=$ & Target & 1987 & $\div$ & Reduction & $\%$ & $=$ & Target \\
\hline Agriculture & 311,000 & $\div$ & 152,400 & 49 & $=$ & 158,600 & 4.400 & $\div$ & 4,000 & 91 & $=$ & 400 \\
\hline UWWTPs & 18,000 & $\div$ & 11,400 & 63 & $=$ & 6,600 & 4.470 & $\div$ & 3,250 & 73 & $=$ & 1,220 \\
\hline Industries & 5,000 & $\div$ & 3 & 60 & $=$ & 2,000 & 1.250 & $\div$ & 1,050 & 84 & $=$ & 200 \\
\hline Total & 334,000 & $\div$ & 166,800 & 50 & $=$ & 167,200 & 10.120 & $\div$ & 8,300 & 82 & $=$ & 1,820 \\
\hline
\end{tabular}

See Carstensen et al. (2006) for details

UWWTPs: urban wastewater treatment plant effluents

Fig. 1 Trends in estimated total nitrogen inputs (solid line) from Denmark to the Danish Straits including the Kattegat since 1900, with 5year averages of point and diffuse sources. Used with the kind permission of Jacob Carstensen, NERI; based on Conley et al. (2007)

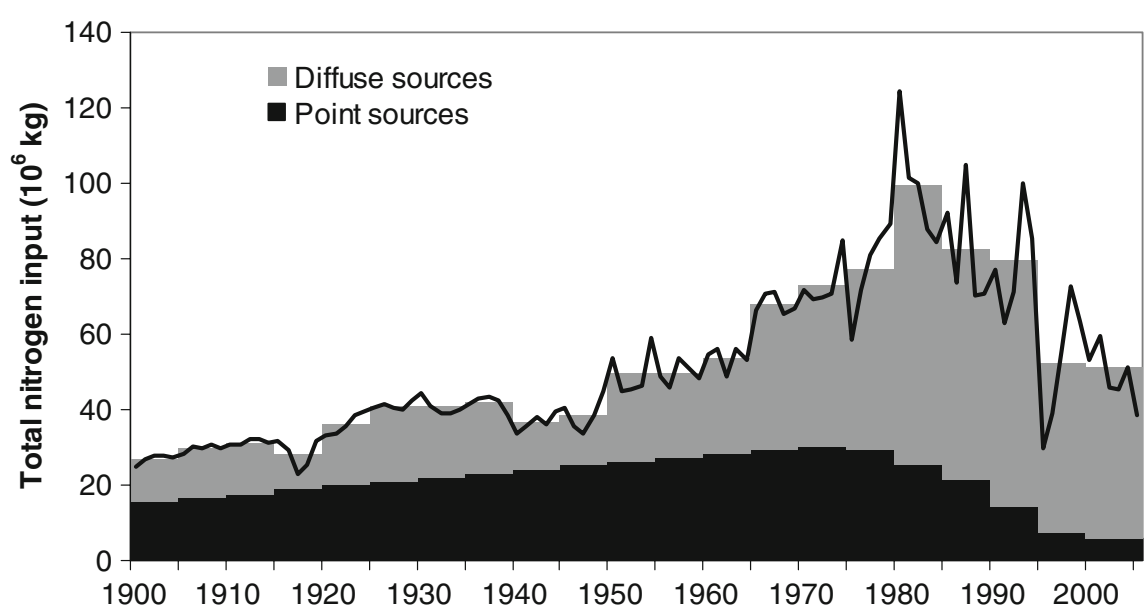

(Hav- og Luftgruppen) as well as indirect financial support from the Danish EPA, Swedish EPA and DHI.

This Special Issue as well as others (Kononen \& Bonsdorf, 2001; Rabalais \& Nixon, 2002; Bachmann et al., 2006) demonstrate that considerable knowledge has been generated since the First Danish Symposium in 1993 . We, as guest editors, are pleased with the Special Issue as compiled and hope that the readers will share this opinion.

Despite the vast knowledge and common understanding of eutrophication, some important gaps still remain, especially with regard to regime shifts, thresholds and multiple stressors. In addition, climate change needs to be taken into account. A fundamental problem that needs to be addressed is the lack of political will to implement adequate nutrient management strategies. A broader acceptance of the need to use the best scientific information we have (whilst still seeking to improve knowledge $=$ "moving whilst improving") rather than wait for 'perfection' is recommended. Finally, it should be kept in mind that we do not manage eutrophication as such, we manage humans with the aim of reducing the effects of eutrophication.

Acknowledgements Thanks are expressed to the Nordic Council of Ministers and the organisers and sponsors of the Second International Symposium on Research and Management of Eutrophication in Coastal Ecosystems. The Preface improved as a result of comments from Jacob Carstensen and Scott W. Nixon. Special thanks go to Sif Johansson, Jørgen Dan Petersen, Jens Brøgger Jensen, Torkil Jønch Clausen, Henning Karup, Jørgen Magner and Morten Søndergaard. We are indebted to the reviewers and to Janet F. Pawlak and Carolyn Symon; this Special Issue would not have been possible but for their helping hands. 


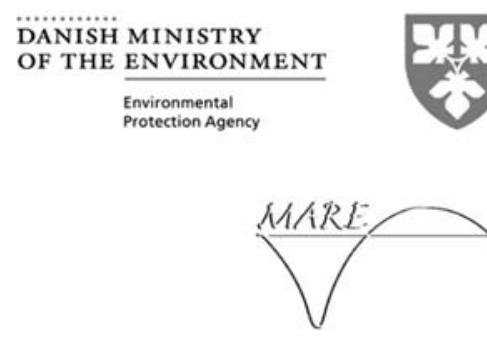

Open Access This article is distributed under the terms of the Creative Commons Attribution Noncommercial License which permits any noncommercial use, distribution, and reproduction in any medium, provided the original author(s) and source are credited.

\section{References}

Anon., 2000. Directive 200/60/EC of the European parliament and of the council of 23 October 2000 establishing a framework for community action in the field of water policy. Official Journal L 327/1.

Bachmann, R. W., J. E. Cloern, R. E. Hecky \& D. W. Schindler (eds), 2006. Eutrophication in freshwater and marine systems. Limnology \& Oceanography 51: 351-800 (Special Issue).

Carstensen, J., D. J. Conley, J. H. Andersen \& G. Ærtbjerg, 2006. Coastal eutrophication and trend reversal: a Danish case study. Limnology \& Oceanology 51: 398-408.

Christensen, P. B., F. Møhlenberg, L. C. Lund-Hansen, J. Borum, C. Christiansen, S. E. Larsen, M. E. Hansen, J. H. Andersen \& J. Kirkegaard, 1998. The Danish marine environment: has action improved its state? Havforskning fra Miljøstyrelsen, Nr. 62. 115 pp.

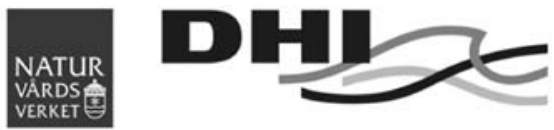

\section{Ill nordon}

Nordic Council of Ministers

Conley, D. J., S. Markager, J. Andersen, T. Ellermann \& L. M. Svendsen, 2002. Coastal eutrophication and the Danish National Aquatic Monitoring and Assessment Program. Estuaries 25: 706-719.

Conley, D. J., J. Carstensen, G. Ærtebjerg, P. B. Christensen, T. Dalsgaard, J. L. S. Hansen \& A. Josefson, 2007. Longterm changes and impacts of hypoxia in Danish coastal waters. Ecological Applications 17: 165-184.

Duarte, C. M., 1995. Submerged aquatic vegetation in relation to different nutrient regimes. Ophelia 41: 87-112.

Jørgensen, B. B. \& K. Richardson (eds), 1996. Eutrophication in Coastal Marine Ecosystems. Coastal and Estuarine Studies, 52. American Geophysical Union, Washington, DC: 273 pp.

Kononen, K. \& E. Bonsdorf (eds), 2001. Man and the Baltic Sea. Ambio 30: 171-326 (Special Issue).

Nixon, S. W., 1995. Coastal marine eutrophication: a definition, social causes, and future concerns. Ophelia 41: 199219.

Rabalais, N. N. \& S. W. Nixon (eds), 2002. Nutrient overenrichment in coastal waters: global patterns of cause and effect. Estuaries 25: 639-900 (Dedicated Issue).

Richardson, K. \& J. P. Heilmann, 1995. Primary production in the Kattegat: past and present. Ophelia 41: 317-328. 